\title{
A Population of Meloidogyne javanica in Spain Virulent to the Mi Resistance Gene in Tomato
}

C. Ornat, S. Verdejo-Lucas, Departament Protecció Vegetal. IRTA. Crta. de Cabrils s/n. 08348 Cabrils, Barcelona, Spain, and F. J. Sorribas, Departament d'Agronomia. ESAB. Comte d'Urgell, 197, 08036 Barcelona

\begin{abstract}
Ornat, C., Verdejo-Lucas, S., and Sorribas, F. J. 2001. A population of Meloidogyne javanica in Spain virulent to the Mi resistance gene in tomato. Plant Dis. 85:271-276.

A population of Meloidogyne javanica virulent to $M i$-gene in tomato was identified in Spain. It reproduced similarly on resistant and susceptible tomato cultivars in the greenhouse, microplots, and in the field. In monoxenic cultures, reproduction of the virulent $M$. javanica was higher than that of an avirulent population on resistant but not on susceptible tomatoes. The virulent population suppressed tomato yield of both resistant and susceptible tomatoes by $29 \%$ in microplots. Initial population density (Pi) was inversely correlated with Pf (final population density)/Pi on both resistant and susceptible tomatoes in the field. A negative correlation was found between $\mathrm{Pi}$ and tomato yield for the susceptible but not for the resistant cultivar.
\end{abstract}

Additional keywords: Lycopersicon esculentum, reproductive potential, root-knot nematode, susceptibility, yield loss

The tomato (Lycopersicon esculentum L.) is the most important horticultural crop in Spain, and is cultivated on approximately 60,000 ha. Production exceeds 3 million tons a year, half used for fresh consumption and the other half for processing. Spain is the largest producer of fresh tomatoes in the European Union with $30 \%$ of total production. This crop is well adapted to most Spanish climatic conditions, and it is cultivated in several crop cycles year round. A wide range of tomato cultivars are grown to meet climatic conditions and market demands.

Meloidogyne spp. are widely distributed and of great economic consequence in the Mediterranean basin. They cause considerable losses in many vegetable, ornamental, and fruit crops $(7,12,16,29,30)$. In order of occurrence, $M$. javanica (Treub) Chitwood, and $M$. incognita (Kofoid \& White) Chitwood are the most widespread species of Meloidogyne, whereas M. arenaria (Neal) Chitwood is less common (9).

Fumigant and non-fumigant nematicides are used to control Meloidogyne on vegetable crops, but increasing environmental concerns and government regulations have contributed to an increased emphasis on other nematode control measures. The use of tomato cultivars resistant to Meloi-

Corresponding author: S. Verdejo-Lucas E-mail: soledad.verdejo@irta.es

Accepted for publication 11 November 2000.

Publication no. D-2001-0112-02R

(C) 2001 The American Phytopathological Society dogyne is an ideal management tactic because it is safe, non-polluting, and requires no input of additional resources by growers. Many commercial tomato cultivars possess the $M i$-gene that confers resistance, but not immunity, to $M$. incognita, $M$. arenaria, and $M$. javanica (27). These cultivars can be grown on most infested land without significant yield loss because they suppress nematode reproduction and are tolerant of initial infection $(17,21,23)$.

Virulent populations of Meloidogyne spp. occur naturally, apparently without previous exposure to or selection by tomatoes with $M i$-gene resistance $(15,22)$. They may also result from selection after repeated exposure to tomatoes with $\mathrm{Mi}$ gene resistance under greenhouse or field conditions $(3,15,24,27)$. The occurrence of virulent populations of Meloidogyne has been reported in several Mediterranean countries in the last decade $(6,10,14,33)$. In this paper we report the reproduction of 14 populations of Meloidogyne from Spain on resistant and susceptible tomato cultivars in a greenhouse test. One population of $M$. javanica was found to produce high numbers of eggs on resistant cultivars. Monoxenic culture, greenhouse, microplot, and field experiments were conducted to confirm the virulence of this population and its impact on tomato yield.

\section{MATERIALS AND METHODS}

Preliminary greenhouse test. Isolates of the following 14 nematode populations were used in the study: two $M$. incognita race 1 (MI-35 and MI-39), one $M$. incognita race 2 (MI-28), and two $M$. incognita race unknown (MI-17 and MI-38), five $M$. javanica (MJ-01, MJ-05, MJ-10, MJ-27, and $\mathrm{MJ}-34$ ), and four $M$. arenaria race 2 (MA-CA, MA-04, MA-12, and MA-26). These isolates came from infested vegetable fields in coastal areas of northeast Spain and had been established as single egg mass lines in monoxenic cultures $(16,30)$. To obtain inocula, nematodes were transferred from monoxenic cultures to potted tomato plants in a greenhouse and allowed to multiply for 8 weeks. Egg inoculum was collected from infected roots with a $0.5 \% \mathrm{NaOCl}$ solution for $5 \mathrm{~min}(8)$. Seedlings of resistant tomato cultivars Carmelo and Luxor and of the susceptible cultivar Precodor were transplanted singly to one-liter pots containing steam-sterilized sand and inoculated with a suspension of 1,000 eggs per plant (one egg per $\mathrm{cm}^{3}$ potted soil) 1 week after transplanting. Each isolate-cultivar combination was replicated seven times, and plants were arranged in a random complete block design on a greenhouse bench. Soil temperature in the pots ranged from 14 to $26^{\circ} \mathrm{C}(x=20)$ during the test. Plants were watered as needed and fertilized with a slow-release fertilizer $(15 \%$ $\mathrm{N}+10 \% \mathrm{P}_{2} \mathrm{O}_{5}+12 \% \mathrm{~K}_{2} \mathrm{O}+2 \% \mathrm{MgO}_{2}+$ microelements). Number of egg masses and eggs per plant were determined 8 weeks after infestation. Eggs were extracted from the whole root system in $0.5 \% \mathrm{NaOCl}$ solution for $10 \mathrm{~min}$ (8). The Pf (eggs per plant)/Pi (egg inoculum) ratio and the index of reproduction $[(\mathrm{Pf}$ on resistant cultivar/Pf on susceptible cultivar) $\times 100$ ] were calculated.

M. javanica MJ-27 virulence. This isolate was obtained from susceptible tomato roots in a naturally infested greenhouse located in Pineda de Mar, Barcelona. Nematode inoculum for the greenhouse and microplot experiments was obtained as described for the preliminary greenhouse test. The nematode virulence was measured by assessing number of eggs or juveniles produced on resistant and susceptible plants.

Monoxenic culture experiment. Reproduction of $M$. javanica $\mathrm{MJ}-27$ was compared with that of the avirulent $M$. javanica isolate MJ-05 (17). Excised root cultures of the resistant tomato cv. Luxor and the susceptible cv. Precodor were prepared on $9 \mathrm{~cm}$-diameter petri dishes containing Gamborg's B5 medium (35). Roots were inoculated with $20 \pm 4$ second-stage juveniles (J2) per root culture. Juveniles were obtained from egg masses collected axenically from monoxenic cultures and 24-h-old J2 were used as inoculum. Each 
isolate $\times$ cultivar combination was replicated six times. Cultures were maintained in an incubator in the dark at $21 \pm 1^{\circ} \mathrm{C}$. Eggs masses were counted 30 days after inoculation. The entire root cultures (infected roots + agar) were placed on modified Baermann funnels to determine viability of eggs produced on the resistant and susceptible tomato cultivars. Hatched juveniles were collected twice per week for 8 weeks, and $\mathrm{J} 2$ counts were added.

Greenhouse experiment. Seedlings of the resistant tomato cvs. Alpado, Carmelo, Nikita, Ramón, Luxor, and Merlin were transplanted singly to one-liter plastic pots containing steam-sterilised sand. The susceptible tomato cvs. Cobra and Laurisilva were included as controls. Five plants of each cultivar were inoculated with a suspension of 1,000 eggs of $M$. javanica MJ27 per plant (one egg per $\mathrm{cm}^{3}$ potted soil) one week after transplanting. Experimental conditions, plant maintenance, and assessment of nematode reproduction were as described for the preliminary greenhouse test. Plants were harvested 9 weeks after soil infestation. Soil temperature in the pots ranged from 13 to $26^{\circ} \mathrm{C}\left(19^{\circ} \mathrm{C}\right.$ on average) during the test. The experiment was repeated once.

Microplots experiment. Round bucketmicroplots (10-liter capacity) filled with a sandy soil (90\% sand, $8 \%$ lime, 2\% clay) were buried in soil in a shade house $(54 \%$ area shaded) at the Experimental Station of the Institut de Recerca i Tecnologia Agroalimentàries (IRTA), Cabrils, Barcelona. Seedlings of the resistant tomato cv. Ramón and susceptible cv. Cobra were transplanted singly to the microplots at the four-true-leaf stage, and five plants of each cultivar were inoculated with a suspension of 10,000 eggs of M. javanica MJ-27 per plant (one egg per $\mathrm{cm}^{3}$ of soil) 1 week after transplanting. Uninoculated plants served as controls. Plants were watered as required and fertilized with the same slowrelease fertilizer used for the greenhouse experiments. Soil temperature during the study ranged from 12 to $27^{\circ} \mathrm{C}\left(20^{\circ} \mathrm{C}\right.$ on average) at $15 \mathrm{~cm}$ depth. Mature fruit was collected twice a week for 12 weeks, starting 8 weeks after transplanting. Tomatoes were counted and weighed. Root galling and nematode reproduction were assessed 20 weeks after inoculation. Root system were rated for galling on a scale of 0 to 10 , where $0=$ complete and healthy root system and $10=$ plants and roots were dead. Nematodes were extracted from two $500 \mathrm{~cm}^{3}$ soil subsamples by using Baermann trays. Trays were left for one week and $\mathrm{J} 2$ that migrated to the clean water were collected, concentrated on a $25 \mu \mathrm{m}$ sieve, and counted. This experiment was repeated once.

Field experiment. The study was conducted in the greenhouse from which $M$. javanica MJ-27 was originally isolated. No other plant-parasitic nematode was detected in the field soil. The greenhouse had a surface of $3,000 \mathrm{~m}^{2}$, and the soil was a loamy sand with a $\mathrm{pH}$ of 8.1 and $3.3 \%$ organic matter. The crop history of the greenhouse, as far as known, was susceptible tomato in spring and lettuce in autumnwinter for 2 consecutive years, and susceptible tomato and radish the season before the initiation of this study. Thirty-two plots of $5.5 \times 3 \mathrm{~m}\left(16.5 \mathrm{~m}^{2}\right)$ were used, and soil samples were taken for nematode analysis. Seedlings of the resistant tomato cv. Ramón were transplanted to 16 plots and the susceptible cv. Cobra to another 16 plots in a random complete block design. Plants were spaced $50 \mathrm{~cm}$ apart in the row, and there was $70 \mathrm{~cm}$ between rows (2.9 plants per $\mathrm{m}^{2}$ ). Soil samples were collected before planting and at the final harvest 20 weeks after transplanting. Individual samples consisted of five soil cores $(2.5 \mathrm{~cm}$ diameter $\times 30 \mathrm{~cm}$ deep) taken from each plot. Soil cores were mixed thoroughly, and a $500 \mathrm{~cm}^{3}$ subsample was used for nematode extraction on Baermann trays. Juveniles were collected one week later and counted and expressed per $250 \mathrm{~cm}^{3}$ of soil. After final harvest, six root systems from each plot were rated for galling as described earlier. To confirm infestation of the greenhouse by $M$. javanica, infected root samples from the resistant and susceptible cultivars were collected at random. Females were extracted from the roots by blender maceration, collected individually, and the esterase phenotype of 40 individual females from each cultivar was determined.

The effect of $M$. javanica MJ-27 on yield was assessed from six plants in each of eight randomly selected plots planted either with resistant or susceptible tomato. Fruits of 48 plants per cultivar were harvested twice a week for 7 weeks, counted and weighed. Agronomic practices including fertilization and irrigation were carried out by the grower and results from this study represent grower's conditions.

In a second test, seedlings of the resistant tomato cv. Ramón were transplanted to eight $M$. javanica infested plots at the same site following the procedure described previously. Nematode densities were determined at planting and after 12 weeks, when the crop was abandoned due to poor crop performance.

Data analysis. Statistical analyses were performed using the linear model procedure of SAS (6.12 SAS, Cary, NC). As no

Table 1. Egg mass production, multiplication rate (Pf/Pi), and reproductive index of 14 populations of Meloidogyne from Spain on Mi-gene resistant tomato cvs Carmelo and Luxor, and the susceptible cv Precodor 8 weeks after the inoculation of 1,000 eggs per plant in a greenhouse ${ }^{\mathrm{x}}$

\begin{tabular}{|c|c|c|c|c|c|c|c|c|c|}
\hline \multirow{2}{*}{\multicolumn{2}{|c|}{ Nematode population }} & \multicolumn{3}{|c|}{ Egg masses per plant } & \multicolumn{3}{|c|}{$\mathbf{P f} / \mathbf{P i}$} & \multicolumn{2}{|c|}{ Reproductive index ${ }^{y}$} \\
\hline & & \multirow{2}{*}{$\begin{array}{c}\text { Carmelo } \\
117 \mathrm{a}\end{array}$} & \multirow{2}{*}{$\begin{array}{l}\text { Luxor } \\
133 \mathrm{a}\end{array}$} & \multirow{2}{*}{$\begin{array}{c}\text { Precodor } \\
216 \mathrm{abc}\end{array}$} & \multirow{2}{*}{$\begin{array}{c}\text { Carmelo } \\
37 \mathrm{a}\end{array}$} & \multirow{2}{*}{$\frac{\text { Luxor }}{40 \mathrm{a}}$} & \multirow{2}{*}{$\begin{array}{c}\text { Precodor } \\
73 a b c\end{array}$} & \multirow{2}{*}{$\begin{array}{c}\text { Carmelo } \\
51\end{array}$} & \multirow{2}{*}{$\begin{array}{l}\text { Luxor } \\
55\end{array}$} \\
\hline M. javanica & MJ-27 & & & & & & & & \\
\hline & MJ-34 & $2 \mathrm{bc}$ & $6 \mathrm{bcd}$ & $206 a b c$ & $1.9 \mathrm{bc}$ & $4.5 \mathrm{bcd}$ & 69 abcd & 2.7 & 6.5 \\
\hline & MJ-05 & $3 \mathrm{bc}$ & $10 \mathrm{bc}$ & $236 \mathrm{abc}$ & $1.5 \mathrm{bc}$ & $4 \mathrm{bcd}$ & $79 a b c$ & 1.8 & 5 \\
\hline & MJ-01 & $7 \mathrm{bc}$ & $9 \mathrm{bc}$ & $257 \mathrm{ab}$ & $4 \mathrm{bc}$ & $5 \mathrm{~b}$ & $115 \mathrm{ab}$ & 3.7 & 4 \\
\hline & MJ-10 & $7 \mathrm{bc}$ & $n a^{\mathrm{z}}$ & $298 \mathrm{a}$ & $2.5 \mathrm{bc}$ & na & $153 \mathrm{a}$ & 1.6 & $\mathrm{n} \mathrm{a}$ \\
\hline & Average & $27 \mathrm{~A}$ & $32 \mathrm{~A}$ & $243 \mathrm{~A}$ & $9.4 \mathrm{~A}$ & $11 \mathrm{~A}$ & $98 \mathrm{~A}$ & 10 & 14 \\
\hline \multirow{6}{*}{ M. incognita } & MI-28 & $47 \mathrm{ab}$ & $36 \mathrm{~b}$ & $100 \mathrm{abc}$ & $9 \mathrm{~b}$ & $9.4 \mathrm{~b}$ & $32 \mathrm{bcd}$ & 28 & 29 \\
\hline & MI-17 & $0 \mathrm{c}$ & $44 \mathrm{bcd}$ & $185 \mathrm{abc}$ & $0.2 \mathrm{bc}$ & 11 bcde & $71 \mathrm{abc}$ & 0.3 & 15 \\
\hline & MI-35 & $0 \mathrm{c}$ & $0 \mathrm{e}$ & $118 \mathrm{abc}$ & $0.02 \mathrm{c}$ & $0.1 \mathrm{e}$ & $18 \mathrm{~d}$ & 0.1 & 0.6 \\
\hline & MI-38 & $0 \mathrm{c}$ & $0 \mathrm{e}$ & $93 \mathrm{c}$ & $0.04 \mathrm{c}$ & $0.2 \mathrm{e}$ & $24 \mathrm{~cd}$ & 0.2 & 0.6 \\
\hline & MI-39 & $11 \mathrm{c}$ & $1 \mathrm{de}$ & $180 \mathrm{abc}$ & $5.5 \mathrm{bc}$ & $0.2 \mathrm{de}$ & $58 \mathrm{abc}$ & 9 & 0.4 \\
\hline & Average & $12 \mathrm{~B}$ & $16 \mathrm{~B}$ & $136 \mathrm{~B}$ & $2.9 \mathrm{~B}$ & $4 \mathrm{~B}$ & $41 \mathrm{~B}$ & 7 & 10 \\
\hline \multirow[t]{5}{*}{ M. arenaria } & MA-04 & $13 \mathrm{c}$ & 2 cde & $111 \mathrm{abc}$ & $2.8 \mathrm{bc}$ & 1.9 bcde & 49 abcd & 5.6 & 3.8 \\
\hline & MA-CA & $2 c$ & $2 \mathrm{cde}$ & $102 b c$ & $0.3 \mathrm{bc}$ & 1.3 bcde & 48 abcd & 0.7 & 2.8 \\
\hline & MA-12 & $18 \mathrm{bc}$ & 5 bcde & $137 \mathrm{abc}$ & $3.5 \mathrm{bc}$ & 0.5 cde & 48 abcd & 7.2 & 1.1 \\
\hline & MA-26 & $0 \mathrm{c}$ & $1 \mathrm{de}$ & $164 \mathrm{abc}$ & $0.1 \mathrm{c}$ & $0.2 \mathrm{de}$ & $72 a b c$ & 0.2 & 0.3 \\
\hline & Average & $8 \mathrm{~B}$ & $2 \mathrm{~B}$ & $128 \mathrm{~B}$ & $1.6 \mathrm{~B}$ & $1 \mathrm{~B}$ & $54 \mathrm{~B}$ & 3 & 2 \\
\hline
\end{tabular}

${ }^{x}$ Each value is mean of seven replications. Statistical analyses of data were based on $\log _{10}(x+1)$ transformed data. Means within a column followed by the same letter in lower case indicate no difference among populations, and in upper case indicate no difference among species according to Tukey test $(P=0.05)$.

y Eggs per plant on resistant cultivar divided by susceptible cultivar $\times 100$.

${ }^{\mathrm{z}}$ Not available. 
significant differences existed between the repeated experiments, results were pooled for statistical analysis. Data on nematode reproduction in monoxenic culture, microplots, and field experiments were transformed to $[\log (x+1)]$ and compared by the Student $t$ test. Data from the greenhouse studies were subjected to analysis of variance followed by mean separation with the Tukey test. In the microplot experiment, yield data from inoculated and uninoculated plants of each cultivar were compared with Student $t$ test. The relationship between $\mathrm{Pi}$ and $\mathrm{Pf} / \mathrm{Pi}$, and between $\mathrm{Pi}$ and yield in the field experiment were determined by regression analysis.

\section{RESULTS}

Preliminary greenhouse test. Across species, the $\mathrm{Pf} / \mathrm{Pi}$ of the three Meloidogyne species (14 populations) was higher $(P \leq$ $0.05)$ on the susceptible than on the resistant tomato cultivars (data not shown). Reproduction of $M$. javanica and $M$. arenaria (490 and 480 eggs per female, respectively) were higher $(P \leq 0.05)$ than $M$. incognita females $(330$ eggs per female) regardless of the tomato cultivar. $M$. javanica showed a $\mathrm{Pf} / \mathrm{Pi}$ relationship higher $(P \leq 0.05)$ than $M$. incognita or $M$. arenaria on the susceptible as well as on the resistant cultivars (Table 1). Females of $M$. javanica produced similar numbers of eggs on resistant (576 and 545 eggs per female on Carmelo and Luxor, respectively) and susceptible tomatoes (384 eggs per female). Across populations, the $\mathrm{Pf} / \mathrm{Pi}$ on the susceptible cultivar was variable and ranged from 18 to 153 times the Pi. On resistant cultivars, the majority of $M$. incognita and $M$. arenaria populations showed reproductive indices lower than $10 \%$, with the exception of $M$. incognita MI-28 that showed a moderate reproduction level. Two isolates of $M$. incognita, MI-35 and MI-38, showed a low Pf/Pi on both susceptible and resistant cultivars. $M$. javanica MJ-27 was the only population that showed high reproductive rates on resistant cultivars.

Monoxenic culture experiment. The virulent $M$. javanica $\mathrm{MJ}-27$ produced more $(P \leq 0.05)$ egg masses and had a higher $\mathrm{Pf} / \mathrm{Pi}$ ratio than the avirulent $\mathrm{MJ}-05$ on the resistant tomato but there was no difference on the susceptible cultivar (Table 2). The susceptible cultivar supported higher $(P \leq 0.05)$ reproduction of $M$. javanica MJ-27 than did the resistant one; only $35 \%$ of the $\mathrm{J} 2$ inoculum became fecund females on the resistant tomato compared with $60 \%$ on the susceptible cultivar. Nevertheless, fecund females produced similar numbers of offspring on both tomato cultivars; 314 and $380 \mathrm{~J} 2$ per female on the resistant and susceptible cultivars, respectively. Most eggs $(90 \%)$ produced on either resistant or susceptible cultivar hatched during the first 3 weeks after being placed on Baermann funnels, but eggs of M. javanica MJ-27 from susceptible tomato roots continued hatching for an additional 5 weeks. This additional hatching was responsible for the significant difference found $(P \leq 0.05)$ between the accumulated number of $\mathrm{J} 2$ recovered from each tomato cultivar.

Greenhouse experiment. The virulent MJ-27 population reproduced on each of the five resistant cultivars tested, though some variation occurred between cultivars (Table 3). Female fecundity varied among cultivars, from 453 to 895 eggs per female on cvs. Cobra and Carmelo, respectively. When data were pooled and compared nematode reproduction was higher $(P \leq$ $0.05)$ on susceptible than on resistant cultivars though both showed a similar Pf/Pi. Because nematode increase on the susceptible cv. Laurisilva was 1.5 times higher than on cv. Cobra, values of the reproductive index were lower when cv. Laurisilva was used as the reference cultivar.

Microplot experiment. Reproduction of the virulent MJ-27 did not differ $(P \leq 0.05)$ on resistant or susceptible cultivars (Table 4). The nematode increased the fresh root weight, but decreased accumulated yield of both cultivars. The yield reduction was due to the lower weight of the fruit produced by the nematode-infected resistant cultivar, and to both the lower number and weight of fruit from the nematode-infected susceptible cultivar. The percentage yield reduction (29\%) caused by the virulent MJ-27 was similar on both resistant and susceptible cultivars.

Field experiment. Densities of the MJ27 population before transplanting tomatoes to plots with the resistant or susceptible cultivars were $582 \pm 706$ (range 4 to 2,840 ) and $312 \pm 444$ (range 18 to 1,672 ) $\mathrm{J} 2$ per $250 \mathrm{~cm}^{3}$ soil $\pm \mathrm{SD}$, and final densities were $1,824 \pm 1,524$ (range 400 to 5,494 ) and $2,710 \pm 1,294$ (range 820 to $5,340) \mathrm{J} 2$ per $250 \mathrm{~cm}^{3}$ of soil, respectively. The population densities did not differ $(P \leq$ 0.05 ) between the resistant and susceptible cultivars either before planting or at final harvest. Resistant and susceptible tomato plants showed similar gall indices: $5.0 \pm$ 2.0 and $5.6 \pm 1.3$, respectively. The typical esterase phenotype of $M$. javanica was observed in every female examined from both resistant and susceptible cultivars.

A highly significant $(P \leq 0.0001)$ negative correlation was observed between the $\mathrm{Pi}$ and the Pf/Pi on the resistant and on the susceptible cultivar (Fig. 1). Both regression lines had a similar slope and intercept value. The nematode population density increased $(\mathrm{Pf} / \mathrm{Pi}>1)$ in each of the 16 plots with the susceptible cultivar, and in 13 of 16 plots with the resistant cultivar. Population densities at or below the equilibrium density $(\mathrm{Pf} / \mathrm{Pi}=1)$ in the remaining three plots occurred at Pi higher than $800 \mathrm{~J} 2$ per

Table 2. Reproduction in monoxenic culture maintained at $21^{\circ} \mathrm{C}$ of a virulent and an avirulent population of Meloidogyne javanica on Mi-resistant and susceptible tomato cultivars inoculated with $20 \pm$ 4 second-stage juveniles per culture ${ }^{\mathrm{X}}$

\begin{tabular}{|c|c|c|c|c|c|}
\hline \multirow[b]{2}{*}{ M. javanica population } & \multicolumn{2}{|c|}{ Resistant cv. Luxor } & \multicolumn{2}{|c|}{ Susceptible cv. Precodor } & \multirow{2}{*}{$\begin{array}{c}\text { Reproduction } \\
\text { index }(\%)^{y}\end{array}$} \\
\hline & Egg masses & $\mathbf{P f} / \mathbf{P i}$ & Egg masses & $\mathbf{P f} / \mathbf{P i}$ & \\
\hline Virulent MJ-27 & $7 \pm 3 a^{z}$ & $101 \pm 69 \mathrm{a}^{\mathrm{z}}$ & $12 \pm 2 \mathrm{a}$ & $234 \pm 74 \mathrm{a}$ & 43.0 \\
\hline Avirulent MJ-05 & $0.5 \pm 0.8 \mathrm{~b}$ & $2.9 \pm 0.5 b$ & $12 \pm 4 \mathrm{a}$ & $196 \pm 42 \mathrm{a}$ & 1.5 \\
\hline
\end{tabular}

${ }^{x}$ Each value is mean of six replications \pm standard deviation.

y Pf on resistant cultivar divided by Pf on susceptible cultivar $\times 100$.

z Indicates differences between nematode populations according to Student $t$ test $(P \leq 0.05)$.

Table 3. Reproduction of a virulent population of Meloidogyne javanica MJ-27 on five Mi-resistant and two susceptible tomato cultivars 60 days after the inoculation with 1,000 eggs per plant in a greenhouse $^{\mathrm{x}}$

\begin{tabular}{|c|c|c|c|c|c|}
\hline \multirow[b]{2}{*}{ Tomato cultivar } & \multirow[b]{2}{*}{ Root weight (g) } & \multirow[b]{2}{*}{ Egg masses/plant } & \multirow[b]{2}{*}{$\mathbf{P f} / \mathbf{P i}$} & \multicolumn{2}{|c|}{ Reproduction index $(\%)^{y}$} \\
\hline & & & & Cobra & Laurisilva \\
\hline \multicolumn{6}{|l|}{$\overline{\text { Resistant }}$} \\
\hline Alpado & $33 \pm 9 a b$ & $488 \pm 175 a$ & $209 \pm 62 \mathrm{ab}$ & 95 & 64 \\
\hline Carmelo & $23 \pm 4 b c$ & $210 \pm 124 b$ & $201 \pm 102 a b$ & 91 & 62 \\
\hline Merlin & $17 \pm 3 c$ & $340 \pm 153 \mathrm{ab}$ & $156 \pm 75 b$ & 71 & 48 \\
\hline Nikita & $26 \pm 9 b c$ & $340 \pm 150 \mathrm{ab}$ & $285 \pm 146 a b$ & 129 & 88 \\
\hline Ramón & $28 \pm 9 a b$ & $430 \pm 105 a$ & $328 \pm 92 \mathrm{a}$ & 149 & 101 \\
\hline \multicolumn{6}{|l|}{ Susceptible } \\
\hline Cobra & $36 \pm 8 a$ & $493 \pm 117 \mathrm{a}$ & $221 \pm 94 \mathrm{ab}$ & & \\
\hline Laurisilva & $33 \pm 10 a b$ & $420 \pm 192 a b$ & $325 \pm 158 \mathrm{ab}$ & & \\
\hline \multicolumn{6}{|l|}{ Average } \\
\hline Resistant & $25 \pm 9$ & $361 \pm 173$ & $236 \pm 114$ & 107 & 84 \\
\hline Susceptible & $34 \pm 10^{z}$ & $456 \pm 167^{z}$ & $273 \pm 137$ & & \\
\hline
\end{tabular}

${ }^{x}$ Data are the combined results of two experiments. Each value is mean of 10 replications \pm standard deviation. Means in columns followed by the same letter are not significantly different according to Tukey Test $(P \leq 0.05)$.

y $\mathrm{Pf}$ on resistant cultivar divided by $\mathrm{Pf}$ on susceptible cultivar $\times 100$.

${ }^{\mathrm{z}}$ Indicates difference $(P \leq 0.05)$ between resistant and susceptible cultivars according to Student $t$ test. 
$250 \mathrm{~cm}^{3}$ soil. Tomato yield did not differ between resistant or susceptible tomatoes; 2.0 and $2.3 \mathrm{~kg}$ per plant, respectively, nor did the average fruit weight (data not shown). Tomato yield decreased as the initial population increased in plots with the susceptible cultivar $(y=-0.4608 x+$ 3.2937; $\left.R^{2}=0.9055 ; P \leq 0.003\right)$, but no correlation was found in plots with the resistant cultivar. In the second field trial, the Pi of the M. javanica $\mathrm{MJ}-27$ population on the resistant cultivar was $49 \pm 50$, and changed to $215 \pm 237 \mathrm{~J} 2$ per $250 \mathrm{~cm}^{3}$ soil after 12 weeks of growth.

\section{DISCUSSION}

Variability in virulence in species and populations of Meloidogyne was confirmed by the results of the preliminary greenhouse test $(26,27)$. This variability was clearer on resistant than on susceptible cultivars. Populations of $M$. javanica multiplied $(\mathrm{Pf} / \mathrm{Pi}>1)$ on nearly all individual plants of the resistant cultivars, whereas populations of $M$. incognita MI-39, $M$. arenaria MA-04, and MA-12 only did on one of the seven replicated plants of the resistant Carmelo, and M. incognita MI-17 did so on one plant of the resistant Luxor. In this experiment and others designed to compare the reproductive potential of populations of $M$. incognita, $M$. javanica, and $M$. arenaria from Spain $(2,31)$, populations of $M$. javanica showed a consistently higher reproductive potential than those of $M$. incognita or $M$. arenaria on resistant and susceptible tomato cultivars. The increased virulence of $M$. javanica has been reported by others (26). This species of Meloidogyne is the most common in many production areas of the Mediterranean basin $(6,9,12,19,33)$ including Spain (16). The moderate to high reproduction of M. javanica populations on resistant tomatoes emphasizes the need for testing resistant cultivars against local populations of the nematode before use for management of Meloidogyne in infested soils.

M. javanica MJ-27 was able to overcome the resistance conferred by the $M i$ gene in $\mathrm{F} 1$ tomato hybrids in five experiments under different experimental conditions, and this population showed an index of reproduction of $53 \%$ in the preliminary greenhouse test, $43 \%$ in monoxenic cultures, $86 \%$ in greenhouse potted plants, and
93\% in the microplot and field experiments. This virulence was demonstrated in experiments involving one or several generations of the nematode, and also on a range of resistant tomatoes. In Spain, populations of Meloidogyne able to increase initial densities on resistant tomatoes have been reported in the Canary Islands (28) and Catalonia. The latter populations showed multiplication rates on resistant cultivars were lower than on susceptible ones in temperature-controlled experiments (30). We have examined over 30 populations of Meloidogyne from Spain for their intraspecific variability and virulence characteristics using differential host tests and $M i$-gene resistant tomatoes, respectively (31), and have found only $M$. javanica MJ-27 to be virulent for the $\mathrm{Mi}$ gene. Hence, the frequency of occurrence of virulent populations of the nematode is low, and this is the first report of a virulent root-knot population in tomato in Spain.

The numbers of egg masses produced on roots by the MJ-27 population in the monoxenic and greenhouse experiments was lower on the resistant than on the susceptible cultivars, but successful J2 that developed into fecund females produced similar numbers of eggs per egg mass on both resistant and susceptible cultivars, suggesting that female fecundity is not affected by the $M i$-gene. The virulent population showed no preference for any of the resistant cultivars tested. It is assumed this virulence occurred naturally because there was no prior exposure of the nematode to the $M i$-gene in the recent cropping history of the greenhouse from which the population was originally isolated. A single female line of the field population was obtained in 1994, and was maintained in monoxenic cultures for eight generations before being used for the monoxenic culture, greenhouse, and microplot studies. The consistency of the results under different experimental conditions indicates that the pathogenicity of the population had not been altered, and that this population has a compatible mechanism overcoming the resistance conferred by $M i$-gene. Castagnone et al. (3) demon-

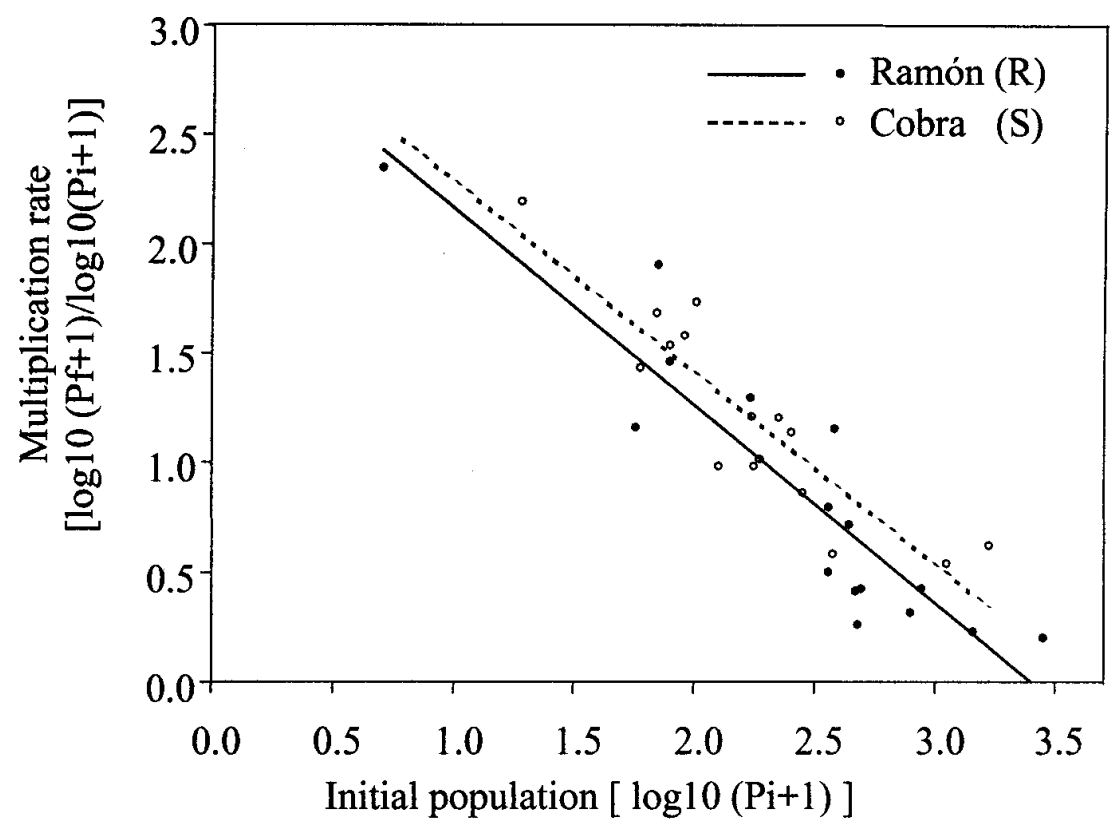

Fig. 1. Correlation between initial population densities of Meloidogyne javanica MJ-27 and multiplication rate $(\mathrm{Pf} / \mathrm{Pi})$ on the resistant tomato cv. Ramón $\left(y=0.8992 x+3.0597 ; R^{2}=0.84\right)$ and susceptible cv. Cobra $\left(y=0.8755 x+3.159 ; R^{2}=0.81\right)$ grown in a greenhouse naturally infested with the nematode.

Table 4. Reproduction of Meloidogyne javanica MJ-27 population, gall index, root weight, and yield of the resistant tomato cv. Ramón and susceptible cv. Cobra inoculated with 10,000 eggs of the nematode per plant in microplots ${ }^{\mathrm{x}}$

\begin{tabular}{|c|c|c|c|c|c|c|}
\hline Tomato cultivar & $\mathbf{P f} / \mathbf{P i}$ & Gall index ${ }^{y}$ & Root weight (g) & Yield (kg/plant) & No. fruits/plant & Average fruit weight (g) \\
\hline \multicolumn{7}{|l|}{ Ramón } \\
\hline Inoculated & $303 \pm 104$ & $6.5 \pm 0.5$ & $207 \pm 82^{z}$ & $1.64 \pm 0.4$ & $17 \pm 5$ & $95 \pm 51$ \\
\hline Uninoculated & & & $103 \pm 23$ & $2.29 \pm 0.6^{z}$ & $19 \pm 5$ & $118 \pm 56^{z}$ \\
\hline \multicolumn{7}{|l|}{ Cobra } \\
\hline Inoculated & $326 \pm 177$ & $6.5 \pm 0.5$ & $148 \pm 33^{z}$ & $1.44 \pm 0.5$ & $15 \pm 2$ & $92 \pm 46$ \\
\hline Uninoculated & & & $87 \pm 15$ & $2.04 \pm 0.1^{z}$ & $19 \pm 4^{z}$ & $105 \pm 48^{z}$ \\
\hline
\end{tabular}

${ }^{x}$ Data are the combined results of two experiments. Each value is mean of 10 replications \pm standard deviation.

y Based on scale from 0 (none) to 10 (severe).

${ }^{\mathrm{z}}$ Indicates differences between inoculated and uninoculated plants of each tomato cultivar according to Student $t$ test $(P \leq 0.05)$. 
strated that the induced virulence from avirulent populations in the laboratory and the natural virulence shown by some populations of $M$. incognita was stable and was maintained after reproduction of the nematode for 18 generations on susceptible tomato cultivars.

Females from either resistant or susceptible cultivars collected in the field site provided diagnostic $M$. javanica isozyme patterns, indicating this was probably the dominant Meloidogyne species at the site. Nevertheless, the virulent population could have displaced other species that may have co-existed before in the site although there is no evidence to support this hypothesis. Mixed species Meloidogyne have not been found in this production area.

The virulent MJ-27 caused similar root galling and percentage yield loss to the resistant and susceptible tomatoes in the microplot experiment. Reproduction of this virulent population in the field tended to be lower on resistant than susceptible cultivars. This tendency was also observed in monoxenic cultures, greenhouse, and microplots. Resistant cultivars apprently retain some of their resistance capability or the virulence of the nematode is incomplete (24). Because residual population densities ( $\mathrm{Pf}$ values) were similar after cropping resistant or susceptible tomato cultivars at the field site, the beneficial effects of planting a resistant cultivar on a subsequent crop were negated due to the virulence of $M$. javanica MJ-27. Other control measures will be needed such as use of nematicides, poor host plants, clean fallow periods, or probably a combination of these to reduce nematode densities.

Management of Meloidogyne with resistant plants has two majors advantages: crop self-protection due to the level of tolerance of resistant plants to injury caused by initial infection, and the rotation value of resistance in cropping systems by suppressing nematode population densities (24). Resistant tomatoes for fresh market consumption were first introduced in the Mediterranean basin in the 1980s, and were reported to suppress nematode densities $(9,20,21,28)$, but later reports indicate that they were not always effective for nematode control perhaps due to a progressive adaptation of Meloidogyne to reproduce on resistant cultivars or a selection for parasitism by its repeated exposure to $\mathrm{Mi}$ resistant tomatoes $(6,28)$. There is, however, no direct evidence of such a process occurring in the field though it has been demonstrated to occur under greenhouse conditions $(4,15)$. Because the $M i$-gene confers resistance but not immunity, nematode reproduction on resistant cultivars in the field can be explained by the inter- and intra-specific variability existing in the genus Meloidogyne, the variable phenotypic expression of the resistance depending on the genotype background $(24,26,27)$, or the allelic composition of the resistance character. Thus, the preliminary greenhouse test and previous studies (31) showed that the Pf/Pi tended to be higher on the resistant Luxor than on Carmelo. The Mi-gene is in an heterozygous state in the majority of the commercial F1 tomato cultivars. Avirulent root-knot populations produce less galling and egg masses on homozygous (MiMi) than heterozygous plants $(1,13)$, but both types of plants respond as susceptible when inoculated with virulent populations regardless of the state of the $M i$-gene $(32,34)$.

Naturally virulent populations of $M$. incognita, $M$. javanica, and $M$. arenaria have been identified $(3,5,15,22,25)$ though those from Mediterranean countries $(6,14,33)$, including Spain were coincidentally all species of $M$. javanica. These populations were identified in greenhouses with two to three crops per year per decade after the introduction of resistant tomatoes. The presence of plant hosts year round, temperatures prevailing inside the greenhouses, and the higher survival rate of the nematode in greenhouses than outdoors (18) may enhance the appearance of resistant breaking populations in intensive agriculture under protected covers. In California processing tomatoes with the $M i$-gene have been grown outdoors as a single crop per year for many years (24), and resistant breaking populations were not detected until 1996 (11). However, no widespread occurrence of these populations in tomato fields has been reported. From a practical standpoint it is important to determine the frequency of virulent populations in a given production area so rotational choice of resistant cultivars and rotational sequences can be properly made. Long-term studies in nematode-infested fields are needed to ascertain if avirulent populations develop to virulent ones after continuous cropping with resistant tomatoes since some populations have shown genetic potential for resistant breaking in controlled selection experiments whereas other populations lack such potential (10). No evidence of resistant breaking biotypes of $M$. javanica was observed after three successive resistant tomato crops in Florida (23). The virulent M. javanica MJ-27, identified by differential host test, perinealpattern morphology, and esterase phenotype, did not differ from other populations of the same species, therefore, rapid diagnosis of virulent populations without the need to bioassay will be desirable since available diagnostic techniques do not distinguish virulent and avirulent forms.

\section{ACKNOWLEDGMENTS}

The first author was recipient of a grant from Instituto Nacional de Investigaciones Agrarias (INIA). This research was supported by INIA grant no. SC95-049. Thanks are given to P. A. Roberts and J. Aramburu for critical reading of the manuscript, and to the Dorlan family for allowing the authors to carry out the field study on their property.
LITERATURE CITED

1. Barham, W. S., and Winstead, N. N. 1957. Inheritance of resistance to Meloidogyne in tomatoes. Proc. Am. Soc. Hortic. Sci. 69:372 377.

2. Busquets, J. O., Sorribas, J., and VerdejoLucas, S. 1994. Potencial reproductor del nematodo Meloidogyne en cultivos hortícolas. Investig. Agrar. Prod. Prot. Veg. 9:1-7.

3. Castagnone-Sereno, P., Bongiovanni, M., and Dalmasso, A. 1993. Stable virulence againts tomato resistance $M i$ gene in the parthenogenetic root-knot nematode Meloidogyne incognita. Phytopathology 83:803-805.

4. Castagnone-Sereno, P., Bongiovanni, M., and Dalmasso, A. 1994. Reproduction of virulent isolates of Meloidogyne incognita on susceptible and Mi-resistant tomato. J. Nematol. 26:324-328.

5. Castagnone-Sereno, P., Wajnberg, E., Bongiovanni, M., Leroy, F., and Dalmasso, A. 1994. Genetic variation in Meloidogyne incognita virulence against the tomato $M i$ resistence gene: Evidence from isofemale line selection studies. Phytopathology 88:749753.

6. Eddaoudi, M., Ammati, M., and Rammah, A. 1997. Identification of resistance breaking populations of Meloidogyne on tomatoes in Morocco and their effect on new sources of resistance. Fundam. Appl. Nematol. 20:285289.

7. Espárrago, G., and Navas, A. 1995. Nematofauna fitoparásita asociada a cultivos hortícolas y tabaco en regadios de Extremadura. Bol. San. Veg. Plagas 21:303-317.

8. Hussey, R. S., and Barker, K. R. 1973. A comparison of methods of collecting inocula of Meloidogyne spp., including a new technique. Plant Dis. Rep. 57:1025-1028.

9. Ibrahim, Y. K. A. 1985. The status of Meloidogyne in the middle east, region VII of the international Meloidogyne project. Pages 373378 in An Advanced Treatise on Meloidogyne. Vol. II: Methodology. K. R. Barker, C. C. Carter, and J. N. Sasser, eds. North Carolina State University, Raleigh.

10. Jarquin-Barberena, H., Dalmasso, A., de Guiran, G., and Cardin, M. C. 1991. Acquired virulence in the plant parasitic nematode Meloidogyne incognita. 1. Biological analysis of the phenomenon. Rev. Nematol. 14:261275 .

11. Kaloshian, I., Williamson, V. M., Miyao, G. Lawn, D. A., and Westerdahl, B. B. 1996. "Resistance-breaking" nematodes identified in California tomatoes. Calif. Agric. 50:18 19

12. Lamberti, F. 1981. Plant nematode problems in the Mediterranean region. Helmintol. Abstr. Ser. B. Plant Nematol. CAB 50:145-166.

13. Laterrot, H. 1973. Selection de varietes de tomate resistantes aux Meloidogyne. OEPP/EPPO Bull. 3:89-92.

14. Molinari, S., and Miacola, C. 1997. Interactions between resistant tomato cvs and Meloidogyne spp. in vitro. Nematol. Mediterr. 25:63-71.

15. Netscher, C. 1976. Observations and preliminary studies on the occurrence of resistance breaking biotypes of Meloidogyne spp. on tomato. Cah. ORSTOM Ser. Biol. 11:173-178.

16. Ornat, C., and Verdejo-Lucas, S. 1999. Distribución y densidad de población de Meloidogyne spp. en cultivos hortícolas de la comarca de El Maresme (Barcelona). Invest. Agrar. Prod. Prot. Veg. 14:191-201.

17. Ornat, C., Verdejo-Lucas, S., and Sorribas, F. J. 1997. Effect of the previous crop on population densities of Meloidogyne javanica and yield of cucumber. Nematropica 27:85-90.

18. Ornat, C., Verdejo-Lucas, S., Sorribas, F. J., and Tzortzakakis, E. A. 1999. Effect of fallow 
and root destruction on survival of root-knot and root-lesion nematodes in intensive vegetable cropping systems. Nematropica 29:5-16.

19. Philis, J. 1983. Occurrence of Meloidogyne spp. and races on island of Cyprus. Nematol. Mediterr. 11:13-19.

20. Philis, J. 1990. The efficacy of nematode resistant tomato cultivars to Meloidogyne javanica under greenhouse conditions. Nematol. Mediterr. 18:209-211.

21. Philis, J., and Vakis, N. 1977. Resistance of tomato varieties to the root-knot nematode Meloidogyne javanica in Cyprus. Nematol. Mediterr. 5:39-44.

22. Prot, J. C. 1984. A naturally occurring resistance breaking biotype of Meloidogyne arenaria on tomato. Reproduction and pathogenicity on tomato cultivars Roma and Rossol. Rev. Nematol. 7:23-28.

23. Rich, J. R., and Olson, S. M. 1999. Utility of $\mathrm{Mi}$ gene resistance in tomato to manage Meloidogyne javanica in North Florida. J. Nematol. 31:715-718.

24. Roberts, P. A. 1995. Conceptual and practical aspects of variability in Meloidogyne related to host plant resistance. Annu. Rev. Phytopa- thol. 33:199-221.

25. Roberts, P. A., Dalmasso, A., Cap, G. B., and Castagnone-Sereno, P. 1990. Resistance in Lycopersicon peruvianum to isolates of $\mathrm{Mi}$ gene-compatible Meloidogyne populations. J. Nematol. 22:585-589.

26. Roberts, P. A., and Thomason, I. J. 1986. Variability in reproduction of isolates of Meloidogyne incognita and $M$. javanica on resistant tomato genotypes. Plant Dis. 70:547551.

27. Roberts, P. A., and Thomason, I. J. 1989. A review of variability in four Meloidogyne spp. measured by reproduction on several hosts including Lycopersicon. Agric. Zool. Rev. 3:225-252.

28. Rodríguez, J. M., and Rodríguez, R. 1991. Resistencia de cultivares de tomate con el gen "Mi" ante poblaciones de Meloidogyne spp. (Nematoda:Tylenchida) en Gran Canaria (Islas Canarias). Bol. San. Veg. Plagas 17:529-535.

29. Rodríguez Rodríguez, A. 1984. El género Meloidogyne en Canarias. 1. Rastreo geográfico preliminar y especies encontradas. Xoba 4:41-51.
30. Sorribas, F. J., and Verdejo-Lucas, S. 1994 Survey of Meloidogyne spp. in tomato production fields of Baix Llobregat county, Spain. J. Nematol. 26:731-736.

31. Sorribas, F. J., and Verdejo-Lucas, S. 1999 Capacidad parasitaria de Meloidogyne spp. en cultivares de tomate resistente. Invest. Agric. Prod. Prot. Veg. 14:237-247.

32. Tzortzakakis, E. A. 1997. Variability in reproduction of Meloidogyne javanica and $M$ incognita on tomato and pepper. Nematropica 27:89-95

33. Tzortzakakis, E. A., and Gowen, S. R. 1996. Occurrence of a resistance breaking pathotype of Meloidogyne javanica on tomatoes in Crete, Greece. Fundam. Appl. Nematol. 19:283-288.

34. Tzortzakakis, E. A., Trudgill, D. L., and Phillips, M. S. 1998. Evidence for a dosage effect of the Mi gene on partially virulent isolates of Meloidogyne javanica. J. Nematol. 30:76-80.

35. Verdejo-Lucas, S. 1995. Dual culture: nematodes. Pages 301-312 in Molecular Methods in Plant Pathology. R. P. Singh and U. S. Singh, eds. Lewis Publishers. Boca Raton, FL. 